\title{
Effects of intraperitoneally injected silver nanoparticles on histological structures and blood parameters in the albino rat
}

This article was published in the following Dove Press journal:

International Journal of Nanomedicine

24 March 2014

Number of times this article has been viewed

\author{
Osama Mohamed M \\ Sarhan ${ }^{1,2}$ \\ Rehab M Hussein ${ }^{3}$ \\ 'Department of Zoology, Faculty \\ of Sciences, Fayoum University, \\ Al Fayoum, Egypt; ${ }^{2}$ Department of \\ Biology, Faculty of Applied Science, \\ Umm Al-Qura University, Makkah \\ Al-Mukarramah, Saudi Arabia; \\ ${ }^{3}$ Department of Zoology, Faculty of \\ Science, Cairo University, Giza, Egypt
}

Correspondence: Rehab M Hussein Department of Zoology, Faculty of Science, Cairo University, Giza, Egypt Tel +20226927224

Email atef_rehab@yahoo.com
Background: The purpose of this study was to investigate the effect of acute dosing with silver nanoparticles (AgNPs) and identify potential ultrastructural alterations in the liver and kidney and their effect on blood parameters in the albino rat.

Methods: Twenty rats were used to assess the acute effects of AgNPs. Rats in the treatment group were injected intraperitoneally with $0.5 \mathrm{~mL}$ of distilled water containing AgNPs at a dose of $2,000 \mathrm{mg} / \mathrm{kg}$ body weight followed by a second injection after 48 hours. Control rats received two $0.5 \mathrm{~mL}$ doses of distilled water only. After 3 days, blood samples were collected, and the rat kidneys and livers were extracted and processed for electron microscopy to investigate for hematologic and histopathologic alterations.

Results: Renal tubules showed swollen epithelium with cytoplasmic vacuolization, thickening of the basement membrane, and destruction of some mitochondrial cristae. Podocytes showed elongation and swelling of their primary and secondary processes. The basement membrane of the capillary tufts became thicker. The hepatic tissue showed narrowing of the sinusoids, swollen hepatocytes with hypertrophied nucleoli, and accumulation of fat globules in the nucleoplasm and cytoplasm. The hepatic sinusoids showed hypertrophied endothelial and Kupffer. Destructed cristae of some mitochondria, endosomes, and larger lysosomes filled with Ag-NPs were also observed in the Kupffer cells. Significant increases were observed in white blood cell count, lymphocyte count, granulocytes, and hemoglobin. There was a significant increase in serum creatinine, urea, and aspartate and alanine aminotransferases.

Conclusion: To the best of the authors' knowledge, the ultrastructural changes in renal and liver tissue observed in this study have not been described before. Our results suggest that injection of AgNPs could have severe cytotoxic effects on the structure and function of these organs.

Keywords: silver nanoparticles, kidney, liver, blood, toxicity, rat

\section{Introduction}

Nanoparticles are engineered materials produced within the nanoscale range of 1-100 nm in one or more dimensions. ${ }^{1}$ Pure silver has the highest electrical and thermal conductivity of all the metals and has low contact resistance. Silver nanoparticles (AgNPs) have unique physical and chemical properties ${ }^{2}$ and have been used in a wide variety of applications. ${ }^{3}$ AgNPs are the best known nanoproducts, ${ }^{4}$ have attracted considerable attention as antimicrobial agents, ${ }^{5}$ and have been incorporated into a number of products, including catheters, clothing, and electrical home appliances due to their high specific surface area and high proportion of surface atoms. ${ }^{6}$ More utilities were added to numerous consumer products including industrial and food products in addition to biological and health and medical applications. ${ }^{78}$ 
Nanosilver with a particle size less than $20 \mathrm{~nm}$ in diameter has been reported to be effective in the treatment of certain infectious diseases, ${ }^{9}$ and is effective in retarding growth of bacteria, mold, and harmful spores. It has been reported that silver is re-emerging as a viable treatment option for infections associated with burns, open wounds, and chronic ulcers. ${ }^{10}$ AgNPs can be ingested directly via water, food, cosmetics, drugs, and drug delivery devices. ${ }^{11}$ Some investigators have demonstrated that silver ions released from ingested products into the blood can accumulate in body organs and have toxic effects, especially in the liver and kidney. ${ }^{12}$ However, acute oral or transdermal doses of AgNPs (2,000 mg/kg body weight) in rats, guinea pigs, and rabbits have not resulted in significant clinical signs, mortality, acute irritation, or corrosive reactions affecting the eyes and skin. ${ }^{13}$ It has been reported that AgNPs are more toxic than other metal nanoparticles, including aluminum, iron, nickel, and manganese, ${ }^{14}$ but the mechanism of their toxicity is not clear. ${ }^{15}$

The aim of this study was to assess the biological risks and benefits of AgNPs. We studied the effect of acute dosing with AgNPs in order to identify potential ultrastructural alterations in the liver and kidney and blood parameters in the albino rat, in the hope of shedding light on the biological responses induced by acute dosing, and to assess cellular responses when these nanoparticles are used in biomedical applications.

\section{Materials and methods}

\section{Silver nanoparticles}

Silver nanopowder with a particle size less than $100 \mathrm{~nm}$ and a 99.9\% trace metals basis was purchased from Sigma-Aldrich Chemicals, Cairo, Egypt. AgNPs have been dissolved in $0.5 \%$ aqueous carboxymethylcellulose (Sigma-Aldrich) were coated with carbon, mounted on an electron microscope grid (200 mesh), ${ }^{16}$ and visualized using a transmission electron microscope ([TEM]; JEM-100CXII, JEOL Ltd., Tokyo, Japan) operating at $80 \mathrm{kV}$. However, AgNPS in the injected doses should be distributed more uniformly by sonication for 10 minutes just before injection, to be taken by systemic circulation.

\section{Experimental animals}

We purchased 20, 6-week-old male albino rats (weighing $260 \pm 5 \mathrm{~g}$ ) from the animal house of Assiut University, Assiut, Egypt. The rats were randomly assigned to polycarbonate cages (five rats per cage), and acclimatized for 10 days at a temperature of $22^{\circ} \mathrm{C} \pm 0.05^{\circ} \mathrm{C}$ and $51 \% \pm 0.5 \%$ humidity with a 12/12 hour-light/dark cycle and access ad libitum to fresh tap water and a rodent diet for 2 weeks before the experiment. The experiments were performed in accordance with the research protocols established by the animal care committee of the National Research Center, Egypt.

\section{Administration of AgNPs}

Twenty rats were randomly allocated into two groups. Five rats were used as controls and injected intraperitoneally with $0.5 \mathrm{~mL}$ of sterile saline solution followed by a second dose after 48 hours. The remaining 15 rats were injected intraperitoneally with AgNPs at a dose of 2,000 mg/kg body weight dissolved in $0.5 \mathrm{~mL}$ of distilled water followed by a second injection after 48 hours. ${ }^{13}$ The rats were euthanized 3 days after the second injection, two blood samples were collected from the left ventricle of each rat under sterile conditions in heparinized tubes for hematology and non-heparinized tubes for biochemistry.

\section{Blood sampling}

The blood samples were taken for a complete blood count, including erythrocytes, total leukocytes, hemoglobin, and hematocrit. Serum from the second blood sample was harvested after centrifugation at 5,000 rpm and stored at $20^{\circ} \mathrm{C}$ until determination of aspartate and alanine aminotransferases, as well as creatinine and urea according to standard methods. ${ }^{17,18}$

\section{Ultrastructural study}

Using 2.5\% glutaraldehyde, small slices of kidney and liver tissue were extracted, fixed immediately, rinsed in $0.1 \mathrm{M}$ sodium cacodylate buffer ( $\mathrm{pH} 7.2$ ), postfixed for 2 hours in $1 \%$ osmium tetroxide. Then they were rewashed with fresh sodium cacodylate buffer and dehydrated in an ascending series of ethanol. The specimens were embedded in Epon $812 .{ }^{19}$ Semithin $(0.5-1 \mu \mathrm{m}$ thickness) and ultrathin (700-800 $\mathrm{A}^{\circ}$ thickness) sections were cut using an LKB ultramicrotome (LKB Produkter AB, Ltd., Stockholm, Sweden). The semithin sections were stained with toluidine blue and the ultrathin sections with uranyl acetate and lead citrate. The stained sections were then examined using the JEM-100CXII operating at $80 \mathrm{kV}$.

\section{Results}

\section{Nanoparticle characterization}

TEM imaging of AgNPs ranging from $20 \mathrm{~nm}$ to $65 \mathrm{~nm}$ in diameter was performed to confirm primary particle size and general morphology. Figures 1 and 2A show aggregation of AgNPs in the size range of 47-65 nm. However, smaller nanomolecules (less than $30 \mathrm{~nm}$ ) appeared to exist as solitary entities (Figure 2B-D). 


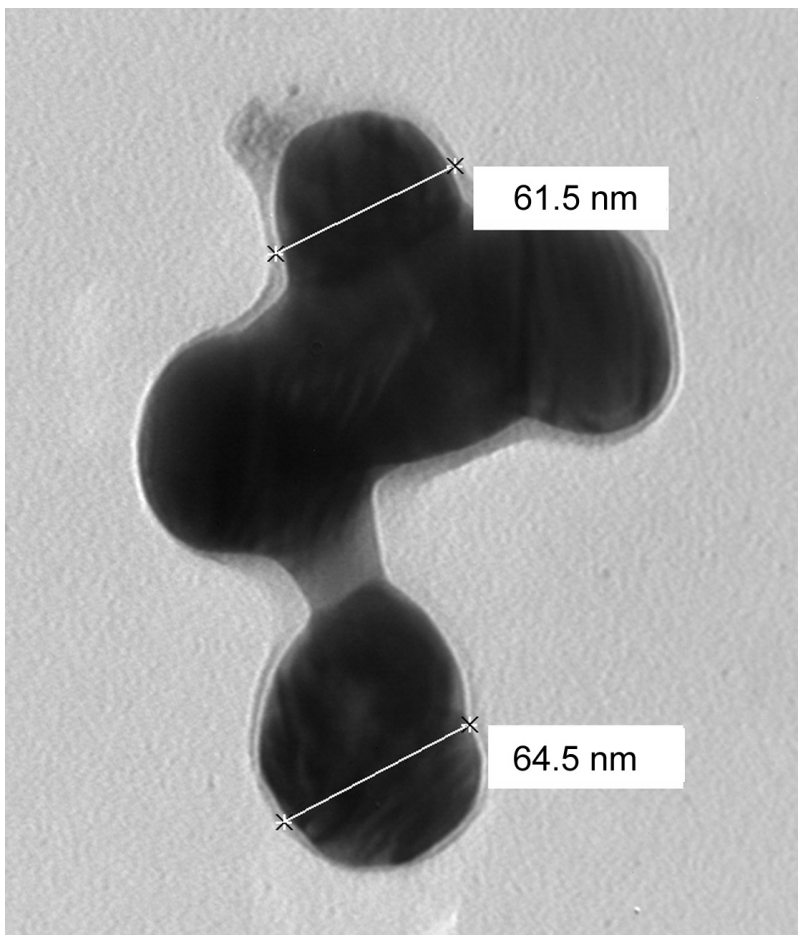

Figure I Transmission electron micrographs on supportive film showing the morphology of silver nanoparticles used in the experiment and indicating variable dimensions. Scale bars 61.5 and $64.5 \mathrm{~nm}$.

\section{Animal symptoms, food consumption, and general activity}

No mortality, gross effects, or significant differences in food consumption or body weight were observed during the study period in any of the rats administered AgNPs when compared with the control group. However, treated rats showed a marked decrease in activity.

\section{Histopathologic investigation}

The treated animals showed distinct morphological changes in the kidney and liver on microscopic observation when compared with the control group, indicating unhealthy cells.

\section{Kidney}

Figure 3 shows the normal histological structure of renal tubules in kidney tissue from the control group. However, the renal cortex in kidney tissue from the treated group shows swollen epithelium and cytoplasm containing numerous membranous vacuoles, with some nuclei showing hypertrophied nucleoli. Figure 4 shows a semithin section of kidney tissue from the treated group, with swelling of the tubular epithelium, cytoplasmic vacuolization,
A

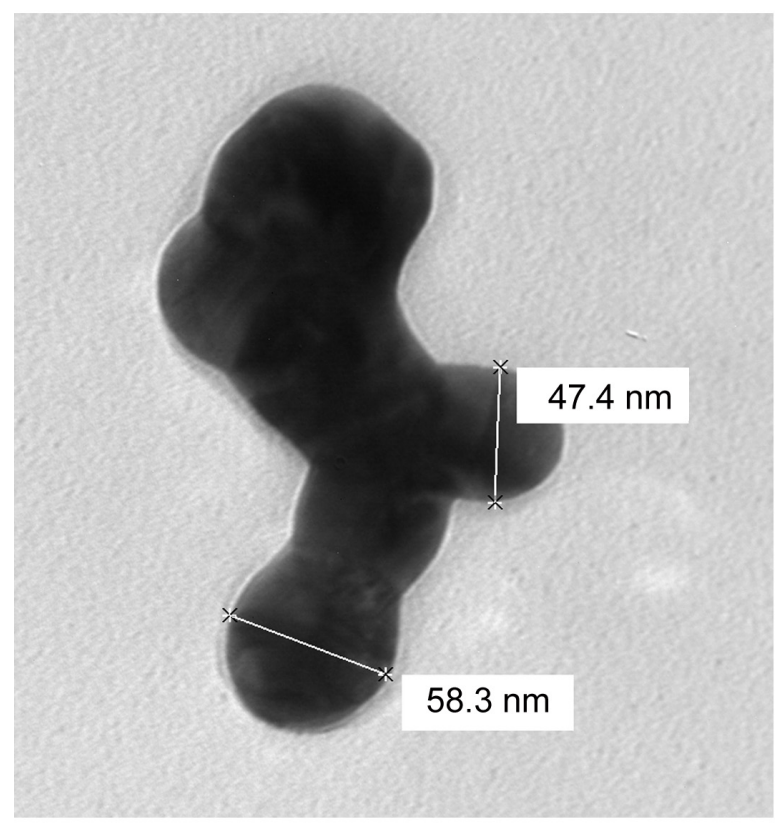

B

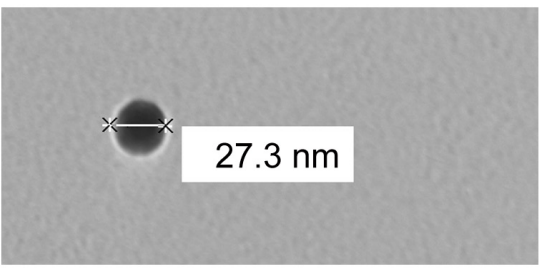

C

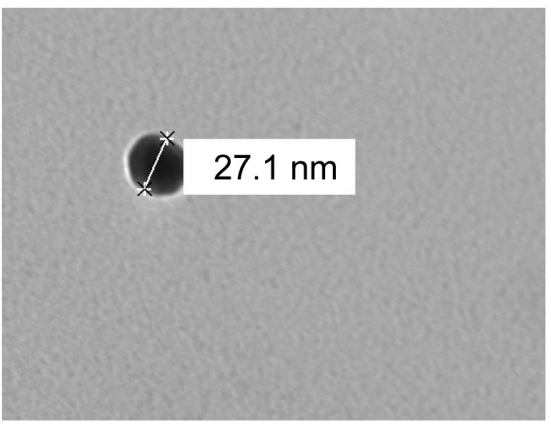

D

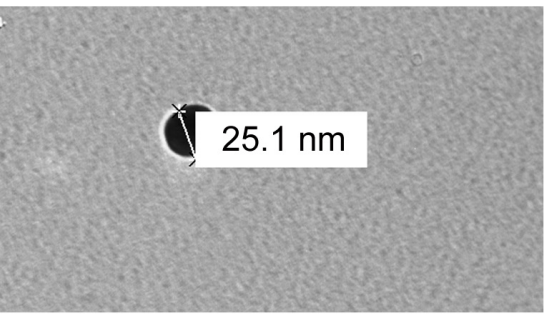

Figure 2 A to $\mathbf{D}$ transmission electron micrographs on supportive film showing the morphology of silver nanoparticles used in the experiment and indicating variable dimensions. Scale bars from $25.1-58.3 \mathrm{~nm}$. 


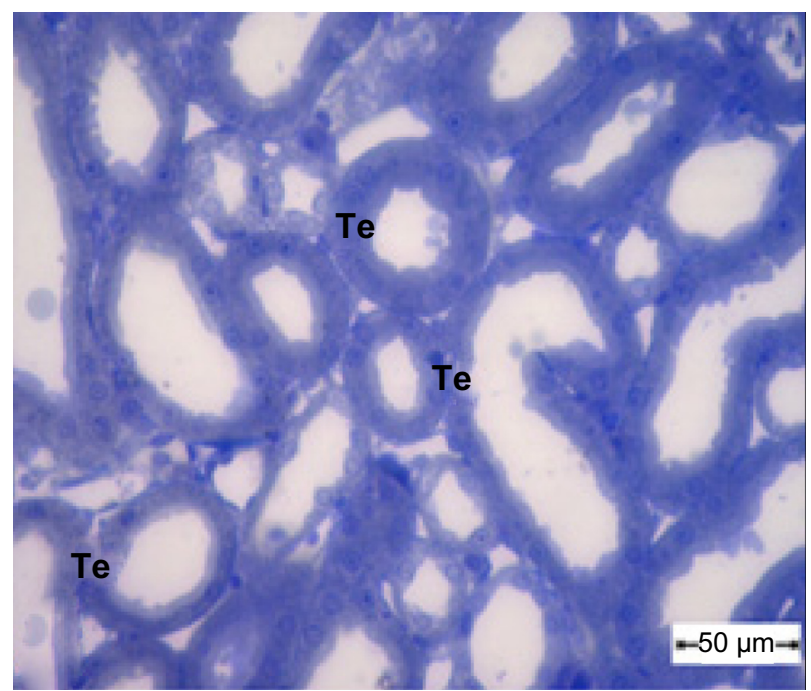

Figure 3 Semithin section of the kidney tubule tissue from the control group showing normal appearance of the tubular epithelium. Scale bar $50 \mu \mathrm{m}$. Abbreviation: Te, tubular epithelium.

glomeruli with increased cellularity, and obliteration of Bowman's space.

Ultrastructural investigations of renal epithelium from control kidney tissue showed a normal brush border, basement membrane, and intact cell organelles, including mitochondria, nuclei, and a few membranous vacuoles (Figure 5). The glomeruli showed normal mesangial cells and a normal basement membrane in the capillary tufts, with some red blood cells in their lumen and normal surrounding primary and secondary processes of intact podocytes (Figure 6). In treated rats, the renal epithelium had a thickened basement

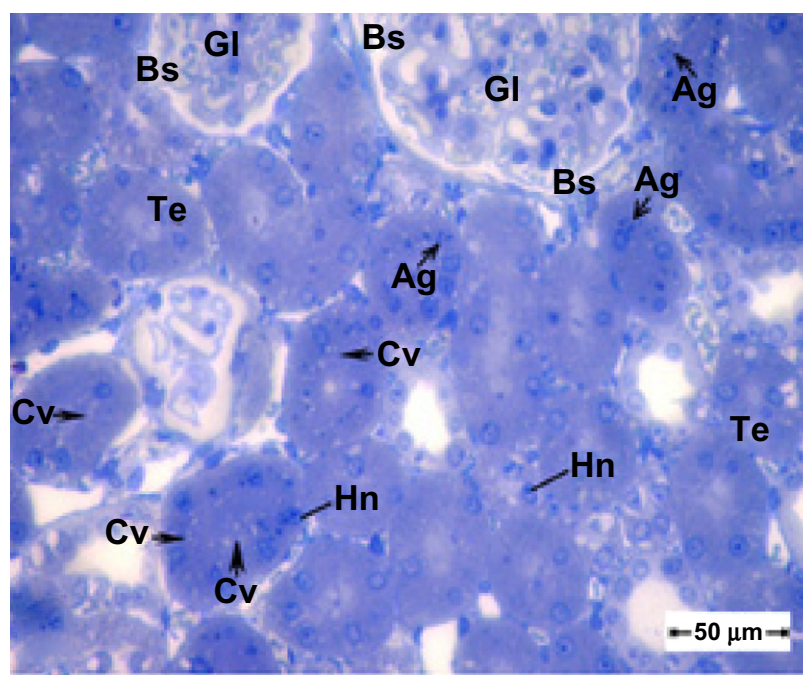

Figure 4 Semithin section of kidney tissue from the treatment group showing swollen tubular epithelium and cytoplasmic vacuolization. Note that the glomeruli show an increase in cellularity and obliteration of Bowman's space. Scale bar $50 \mu \mathrm{m}$. Abbreviations: Ag, silver nanoparticles; Bs, Bowman's space; Cv, cytoplasmic vacuolization; Gl, glomeruli; Hn, hypertrophied nuclei; Te, tubular epithelium.

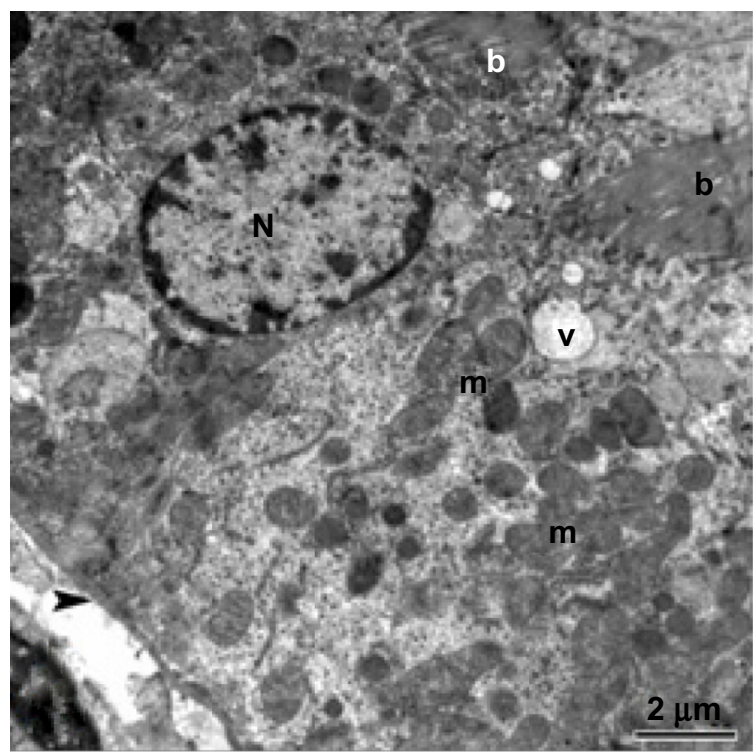

Figure 5 Transmission electron micrograph of kidney tubule tissue from the control group showing normal ultrastructure of the tubular epithelial cell layer in the basement membrane (arrow head). Note the nucleus, mitochondria, brush border, and membranous vesicles. Scale bar $2 \mu \mathrm{m}$.

Abbreviations: b, brush border; $\mathrm{m}$, mitochondria; $\mathrm{N}$, nucleus; $\mathrm{v}$, membranous vesicles.

membrane, and the cytoplasm showed some mitochondria with destroyed cristae and numerous large membranous vesicles (Figures 7 and 8). The glomeruli showed podocytes with swollen and elongated primary and secondary processes, and the basement membrane of the endothelial cells in the capillary tufts was thickened (Figure 9).

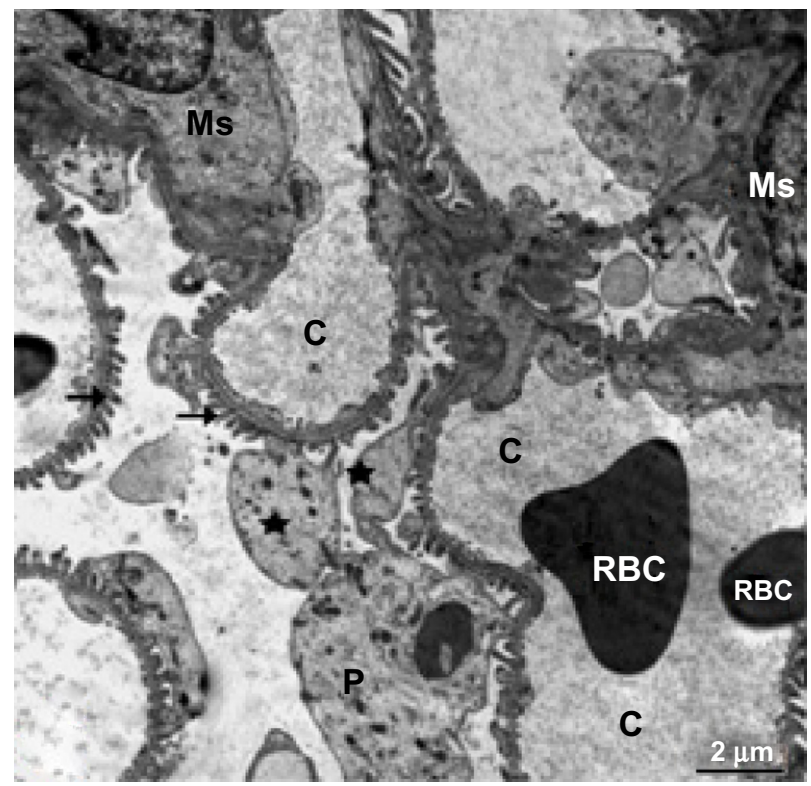

Figure 6 Transmission electron micrograph of kidney glomerular tissue from the control group showing a capillary tuft containing red blood cells, podocytes with primary (star) and secondary (arrows) processes, and mesangial cells. Scale bar $2 \mu \mathrm{m}$. Abbreviations: C, capillary tuft; Ms, mesangial cells; P, podocytes; RBC, red blood cells. 


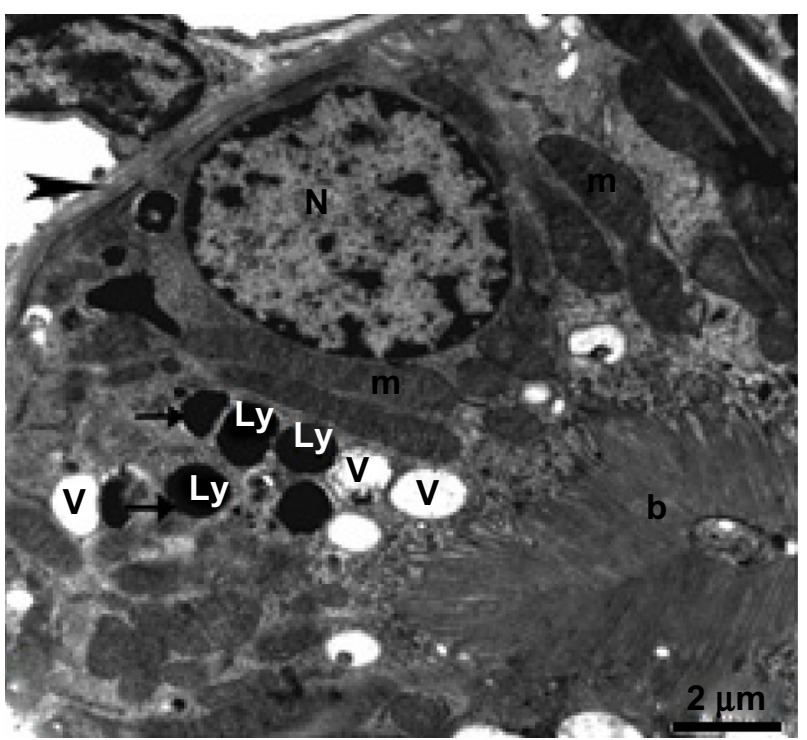

Figure 7 Transmission electron micrograph of kidney tubular epithelium from the treated group showing the nucleus, numerous vesicles, and mitochondria with cristae. The lysosomes are filled with electron-dense nanoparticles varying in size and shape (arrow). Note that the tubular epithelium is lying on a thickened basement membrane (arrow head) and its free surface has a long brush border. Scale bar $2 \mu \mathrm{m}$.

Abbreviations: b, brush border; Ly, lysosomes; m, mitochondria; $\mathrm{N}$, nucleus: $\mathrm{V}$, vesicles.

\section{Liver}

Semithin sections from a sample of control liver tissue demonstrated a normal histological structure (Figure 10), while semithin sections of treated liver tissue showed narrowing of the sinusoidal lumen and damaged hepatocytes (Figure 11). Ultrathin sections of treated liver tissue

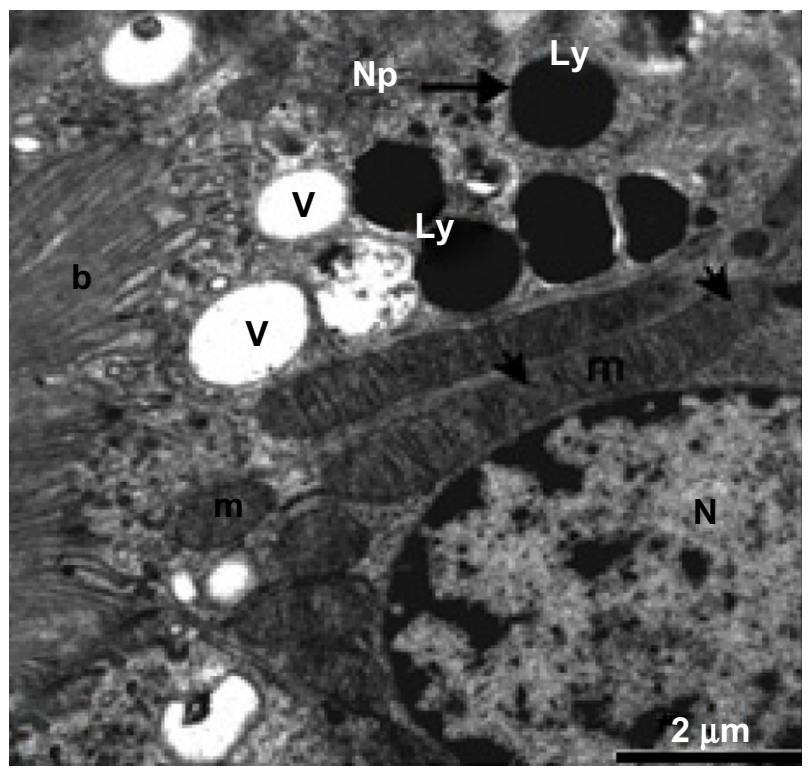

Figure 8 Higher magnification of the previous micrograph showing the nucleus, well developed mitochondria, and membranous vesicles, as well as lysosomes containing electron-dense nanoparticles (thick arrows). Note that some mitochondrial cristae are destroyed (thin arrows). Scale bar $2 \mu \mathrm{m}$.

Abbreviations: b, brush border; Ly, lysosomes; m, mitochondria; $\mathrm{N}$, nucleus; $\mathrm{Np}$, nanoparticles; $\mathrm{V}$, membranous vesicles.

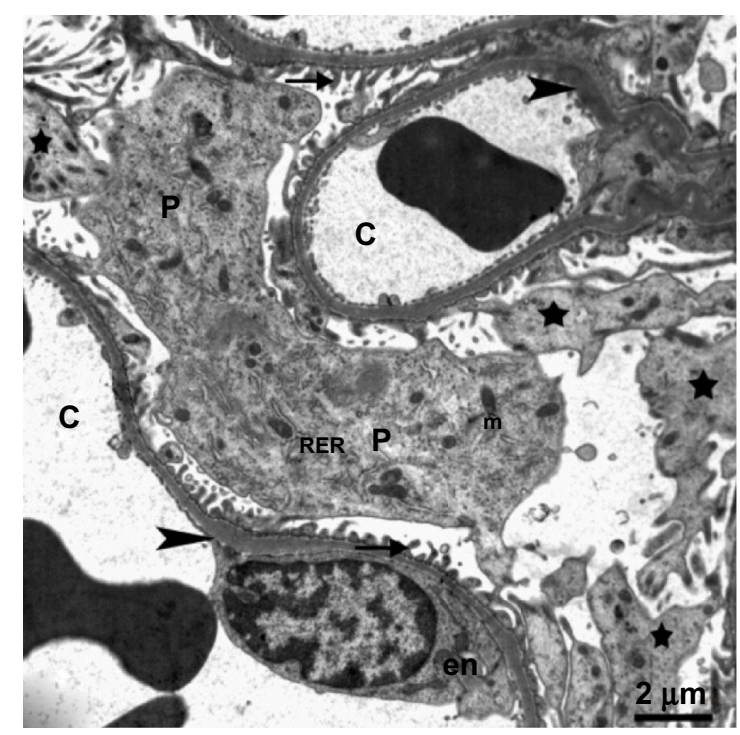

Figure 9 Transmission electron micrograph of kidney glomerular tissue from the treated group showing swollen podocytes with numerous long primary (stars) and secondary processes (arrows) rich in organelles, mitochondria, rough endoplasmic reticulum, and thickening of the basement membrane (arrowhead) in the capillary tuft. The body of an endothelial cell (en) can be seen. Scale bar $2 \mu \mathrm{m}$.

Abbreviations: $C$, capillary; en, endothelial cell; $m$, mitochondria; $P$, podocytes; RER, rough endoplasmic reticulum.

showed swollen hepatic cells, narrowing of the sinusoidal lumen, and appearance of hypertrophied Kupffer cells (Figure 12).

Ultrathin sections from control liver tissue showed normal hepatocytes on TEM. The nuclei had a normal ultrastructural appearance with a distinct nuclear envelope, and the nucleoplasm showed aggregations of euchromatin and heterochromatin granules (Figure 13). Other intact cytoplasmic organelles could be seen, including spheroid or ovoid mitochondria with well-developed cristae and flattened cisternae of rough endoplasmic reticulum studded with ribosomes; in addition, considerable numbers of glycogen

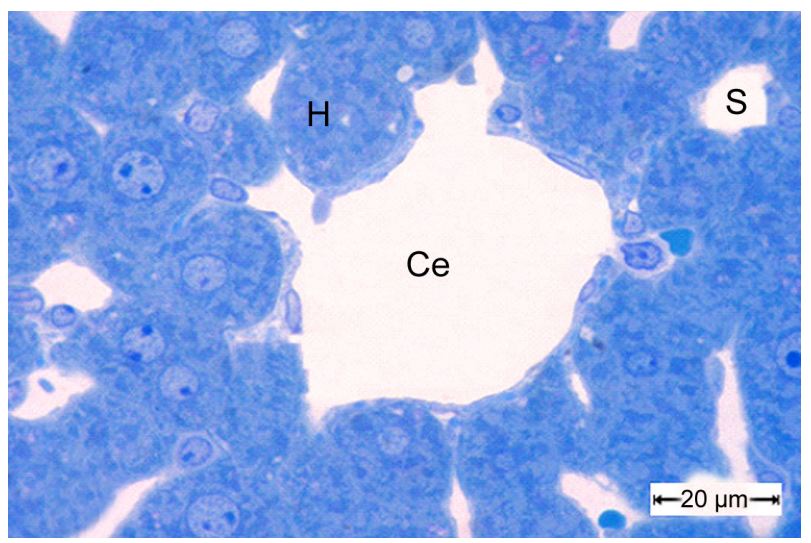

Figure 10 A semithin section of liver tissue from the control group showing the normal cytoarchitecture of the lobule.

Notes: The central vein is surrounded by hepatic cells separated by blood sinusoids. Scale bar $20 \mu \mathrm{m}$.

Abbreviations: $\mathrm{Ce}$, central vein; $\mathrm{H}$, hepatic cells; $\mathrm{S}$, blood sinusoids. 


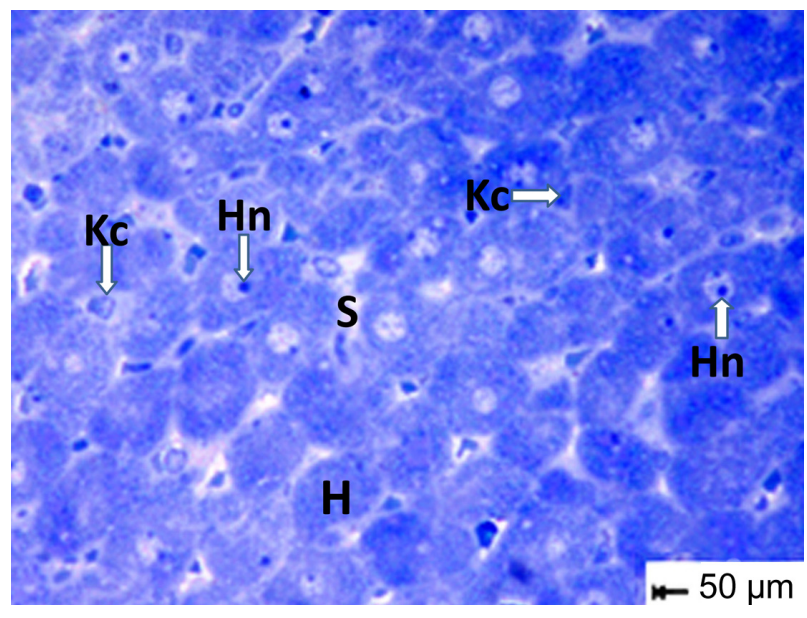

Figure I I Semithin section of liver tissue from the treated group showing narrowing of the sinusoidal lumen. Scale bar $50 \mu \mathrm{m}$.

Abbreviations: $\mathrm{H}$, hepatocytes; $\mathrm{Hn}$, hypertrophied nuclei; Kc, Kupffer cells; s,sinusoidal lumen.

granules were observed in the cytosol (Figure 14). In contrast, marked cytopathological changes were seen in hepatocytes from the treated group. Figure 15 showed a hepatocyte with strong cytoplasmic vacuolization, numerous intranuclear and intracytoplasmic fat globules of various sizes that appeared swollen, with smaller stacks of fragmented rough endoplasmic reticulum cisternae. Numerous intracytoplasmic and intranuclear fat globules of various sizes were intermingled with mitochondria that appeared swollen with obviously condensed electron-dense matrices and some of them without cristae (Figures 15 and 16). Some Kupffer cells showed numerous membranous vacuoles, fragmented rough endoplasmic reticulum cisternae, endosomes, and a large number of lysosomes filled with AgNPs of different sizes that appear

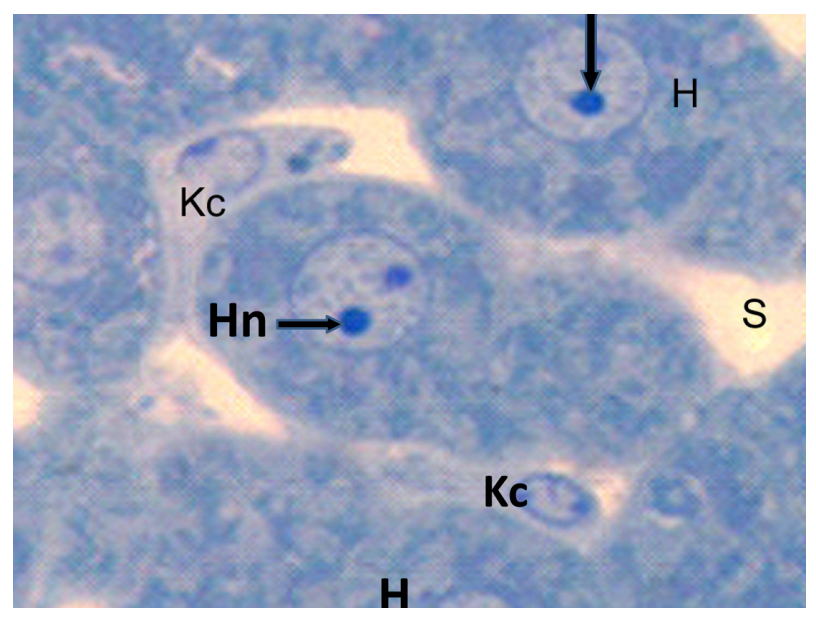

Figure 12 Semithin section of liver tissue from the treated group showing swollen hepatic cells with narrowing of the sinusoidal lumen and hypertrophied Kupffer cells. Scale bar $50 \mu \mathrm{m}$.

Abbreviations: $\mathrm{H}$, hepatic cells; Hn, hypertrophied nuclei; Kc, Kupffer cells; s, sinusoidal lumen.

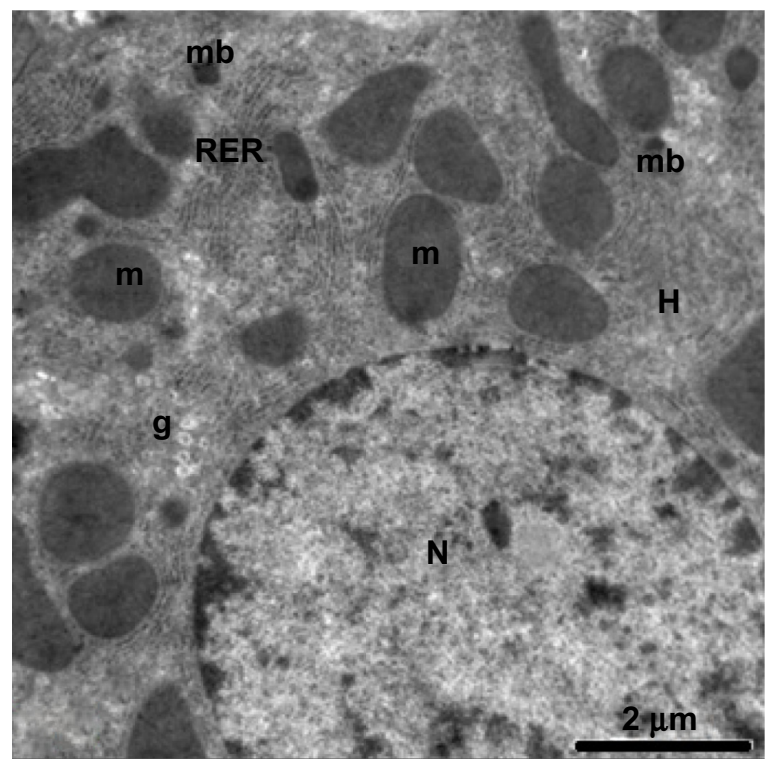

Figure 13 Transmission electron micrograph of a hepatic cell from the control group showing the normal ultrastructure of the hepatic cell, nucleus, mitochondria, rough endoplasmic reticulum, microbodies, and glycogen granules. Scale bar $2 \mu \mathrm{m}$. Abbreviations: g, glycogen granules; $\mathrm{H}$, hepatic cell; $\mathrm{m}$, mitochondria; $\mathrm{mb}$, microbodies; $\mathrm{N}$, nucleus; RER, rough endoplasmic reticulum.

as electron-dense material (Figures 17-19). Disse's spaces contained fragmented microvilli (Figures 18, 20, and 21), and the mitochondria showed complete loss of internal ridges and matrices (Figures 22 and 23). Figure 23 shows degenerated hepatic Kupffer cells and nuclei, with destruction of the

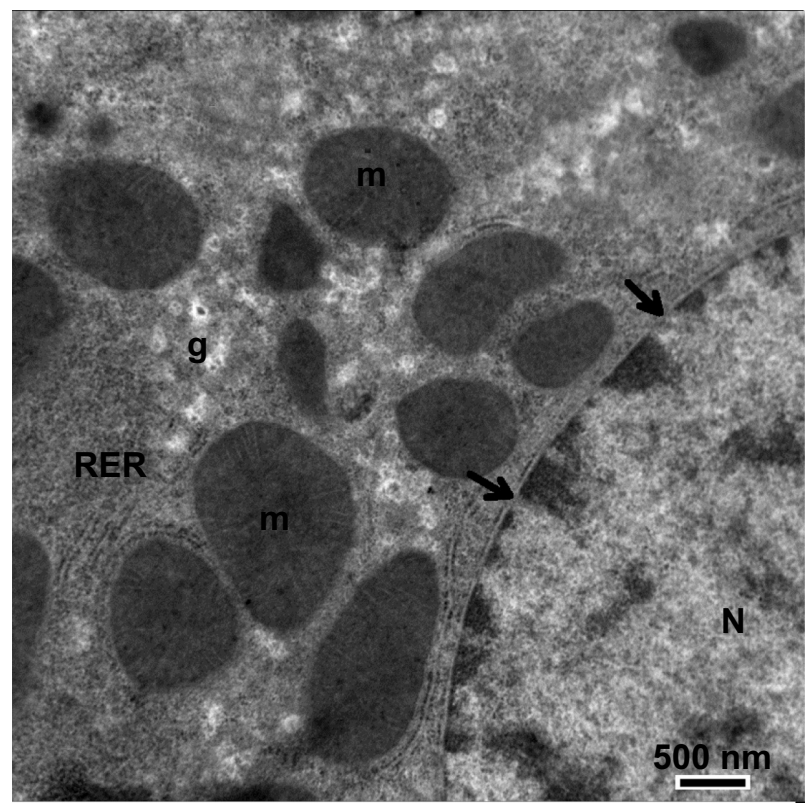

Figure I 4 Magnified micrograph of a hepatic cell from the control group showing the normal ultrastructure of the nucleus and its nuclear membrane, containing nucleopores (arrows), well developed rough endoplasmic reticulum, well developed mitochondria, and glycogen granules. Scale bar $500 \mathrm{~nm}$.

Abbreviations: g, glycogen granules; m, mitochondria; $N$, nucleus; RER, rough endoplasmic reticulum. 


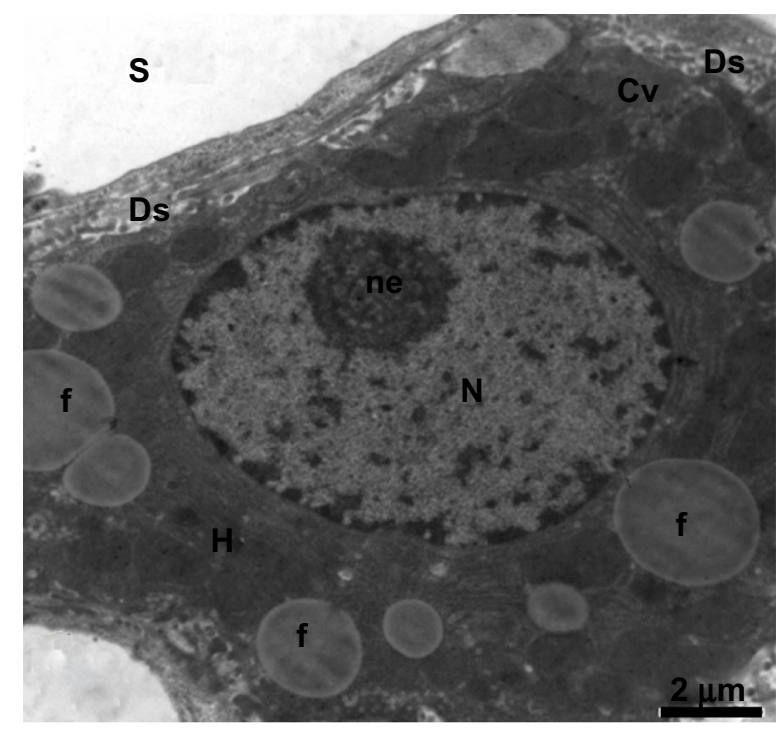

Figure 15 Transmission electron micrograph of a hepatic cell from the treated group containing numerous fat globules and a nucleus with hypertrophied nucleoli. Notice the presence of cytoplasmic vacuolization, the sinusoidal lumen, and Disse's spaces. Scale bar $2 \mu \mathrm{m}$.

Abbreviations: $\mathrm{Cv}$, cytoplasmic vacuolization; Ds, Disse's spaces; $\mathrm{f}$, fat globules; $\mathrm{H}$, hepatic cell; $\mathrm{N}$, nucleus; ne, nucleoli; S, sinusoidal lumen.

microvilli in Disse's spaces and lysosomes filled with AgNPs that appear as electron-dense material.

\section{Hematology and biochemistry}

Complete blood count sampling in the treated group showed a significant increase in white blood cells and hemoglobin, with slight changes in red blood cell and hematocrit values (Table 1). In comparison with the control group, serum alanine and aspartate aminotransferase levels in the treated group were significantly elevated in comparison with those in the control group (Figure 24A and B), indicating disruption of liver function. Serum creatinine and urea were significantly increased, indicating changes in kidney function (Figure 24C and D).

\section{Discussion}

AgNPs have received much attention due to their antimicrobial properties ${ }^{20,21}$ and their potential for application in the treatment of diseases that need a constant drug concentration in the blood or targeting of specific tissue. ${ }^{22-24}$ Despite these beneficial effects, some studies based on actual data from rat models suggesting that AgNPs may be cytotoxic even at low doses, ${ }^{25,26}$ potentially increasing reactive oxygen species, ${ }^{6,27}$ via which phospholipid membranes may be attacked, and decreasing function of the mitochondrial respiratory chain complexes in the liver, brain, and skeletal muscles. ${ }^{28,29}$ Nanoparticles released into the blood have been shown to accumulate, with toxic effects in the liver, kidney, and heart, causing scattered cytoplasmic vacuolization, appearance of

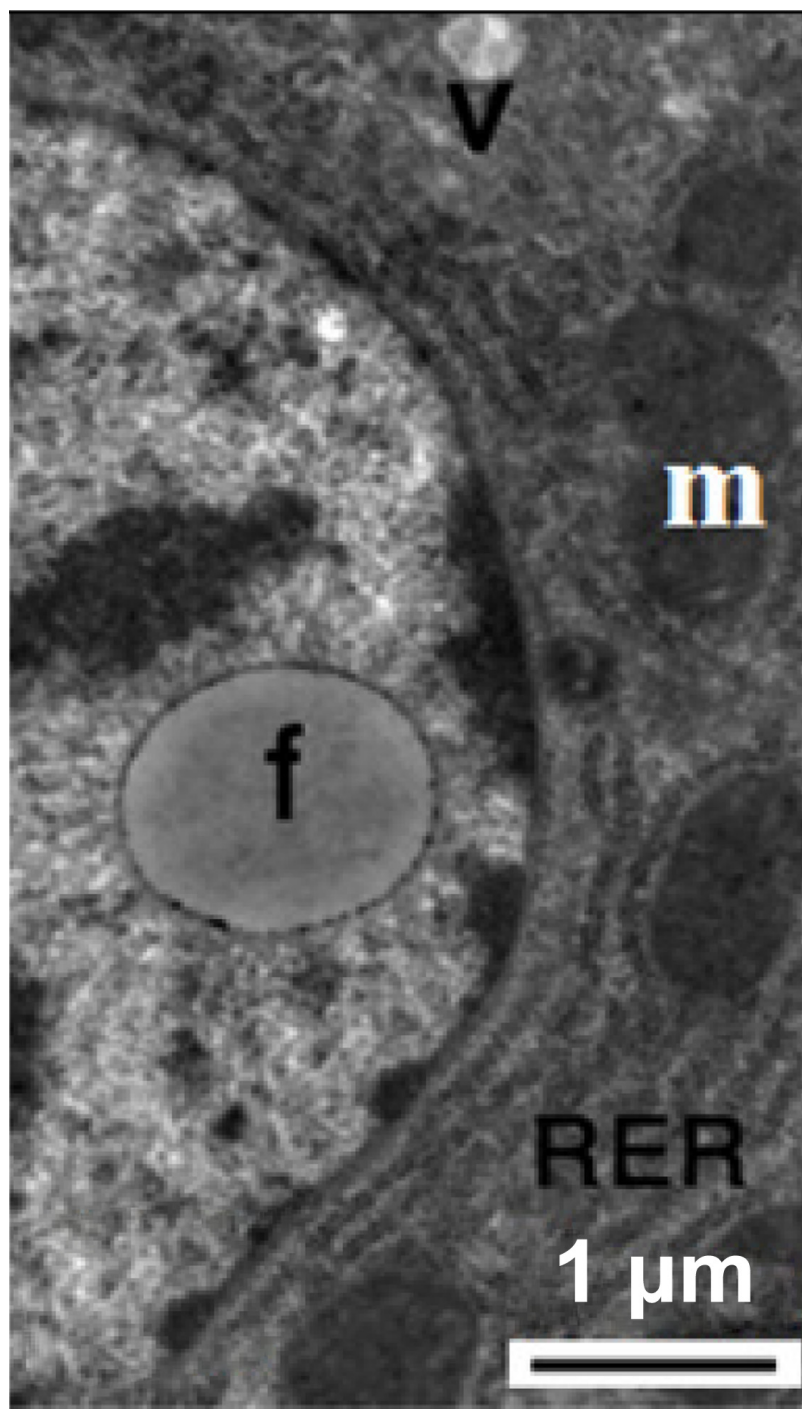

Figure 16 Transmission electron micrograph of a hepatic cell from the treated group showing intranuclear fat globules in the nucleoplasm. Note the well-developed cisternae of the rough endoplasmic reticulum, and the few mitochondria and small membranous vesicles. Scale bar I $\mu \mathrm{m}$.

Abbreviations: $\mathrm{f}$, fat globules; $\mathrm{m}$, mitochondria; RER, rough endoplasmic reticulum; $\mathrm{v}$, membranous vesicles.

chronic inflammatory cells, and congested and dilated blood vessels. $^{12,30}$

The AgNPs used in our study appeared to be very uniform with a mostly spherical morphology and a particle size of 20-60 nm. Spherical, triangular, and hexagonal nanoparticles have better antimicrobial and physical properties if they are produced in a small size range. ${ }^{31}$ Jiang et $\mathrm{al}^{32}$ reported that AgNPs in the 40-50 $\mathrm{nm}$ size range demonstrated the best antimicrobial activity. However, sonification of the dose for 10 minutes immediately before injection may prevent aggregation of AgNPs before they can be taken up by the systemic circulation. The present work demonstrates that nonaggregated AgNPs may have increased hepatic and renal 


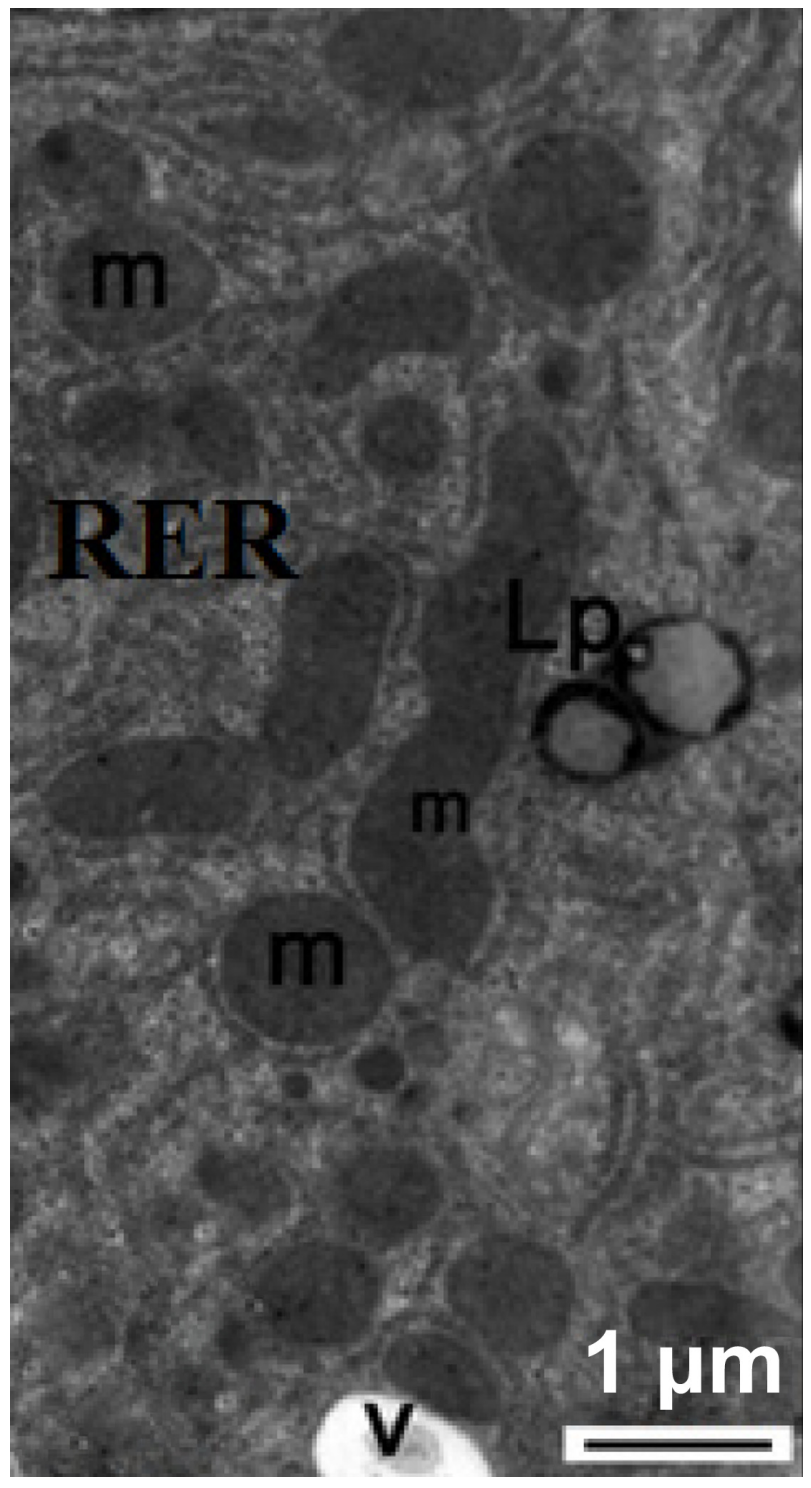

Figure 17 Transmission electron micrograph of a hepatic cell from the treated group showing some lipofuscin pigment, fragmented cisternae in the rough endoplasmic reticulum, and small membranous vesicles. Note the mitochondria. Scale bar I $\mu \mathrm{m}$. Abbreviations: Lp, lipofuscin pigment; $m$, mitochondria; RER, rough endoplasmic reticulum; v, membranous vesicles.

toxicity. Once AgNPs aggregate, significant loss of antibacterial activity occurs due to their inability to penetrate the plasma membrane and loss of surface area. (High School Nanoscience Program). Consequently, the decreased stability of AgNPs may lead to loss of their nanoscale properties. ${ }^{33}$ Further, aggregation of AgNPs decreased their effect and cellular uptake ${ }^{34}$ and modifies their bioavailability and toxicity. ${ }^{35}$

Our study suggests that the toxicity of AgNPs is dosedependent and time-dependent, with more accumulation of silver in the liver than in the kidneys at 3 days post-injection. Limited tissue clearance was observed after 26 weeks in the liver, spleen, and lungs of mice treated with titanium dioxide

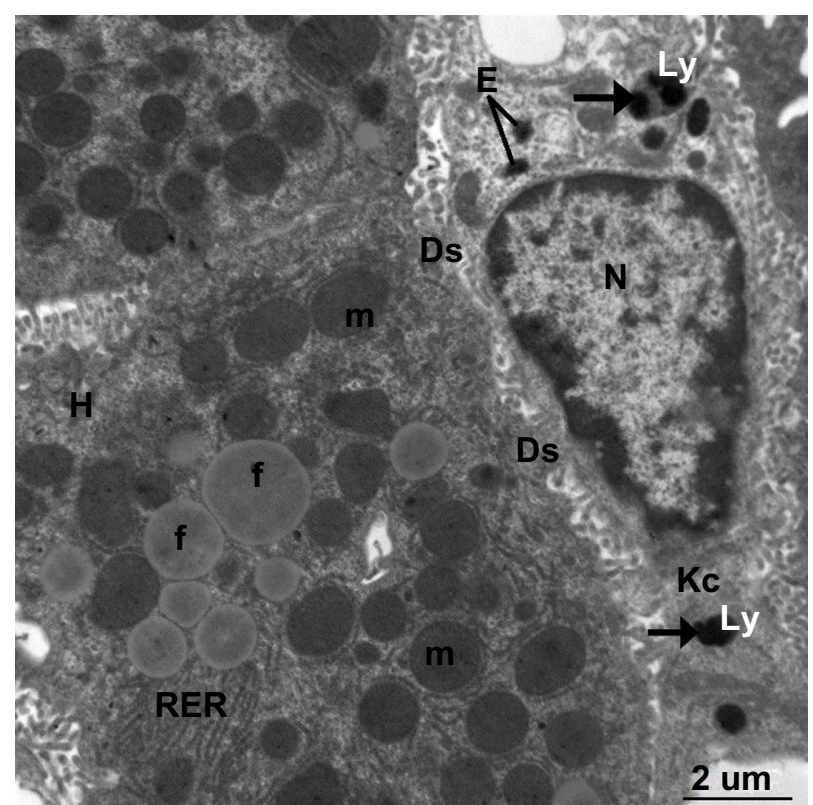

Figure 18 Transmission electron micrograph of a hepatic cell from the treated group containing numerous fat globules, rough endoplasmic reticulum, and mitochondria. Note Kupffer cells containing numerous endosomes and lysosomes filled with electron-dense material of silver nanoparticles (arrows) and the fragmented microvilli in Disse's space could be seen between the hepatic cell and Kupffer cell. Scale bar $2 \mu \mathrm{m}$.

Abbreviations: Ds, Disse's space; E, endosomes; f, fat globules; $H$, hepatocyte; Kc, Kupffer cells; Ly, lysosomes; m, mitochondria; N, nucleus; RER, rough endoplasmic reticulum.

nanoparticles. ${ }^{36}$ However, it has been concluded that the target organs for AgNP toxicity are the liver and kidneys of male and female rats and that deposition of AgNPs in tissue samples is size-dependent. ${ }^{16,37}$ It has also been demonstrated that different sized and shaped gold nanoparticles have different toxicity. ${ }^{38}$

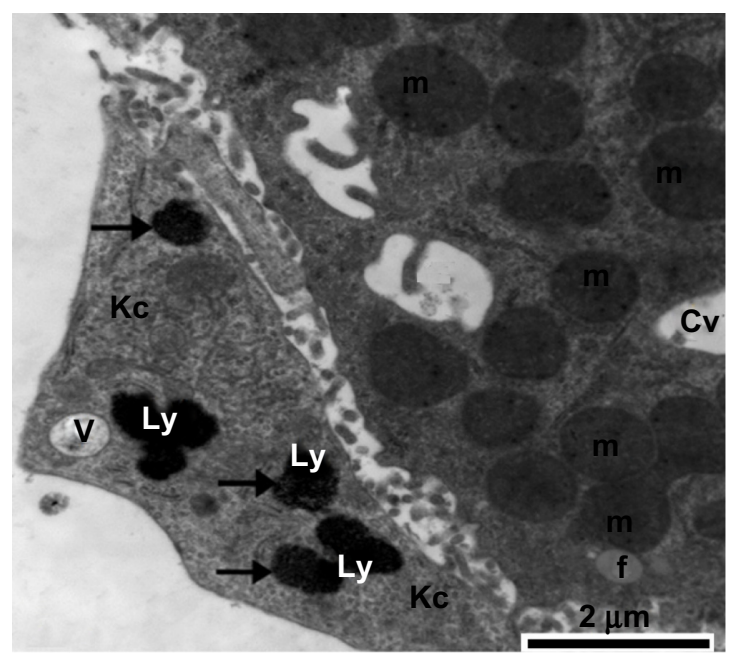

Figure 19 Transmission electron micrograph of a hepatic cell from the treatment group containing a small fat globule and numerous vesicles, fragmented cisternae of rough endoplasmic reticulum, and numerous mitochondria. Also shown is part of a Kupffer cell containing membranous cytoplasmic vacuoles and lysosomes along with electron-dense silver nanoparticles (arrows). Scale bar $2 \mu \mathrm{m}$.

Abbreviations: Cv, cytoplasmic vacuoles; f, fat globule; Kc, Kupffer cell; Ly, lysosomes; $\mathrm{m}$, mitochondria; $\mathrm{V}$, vesicles. 


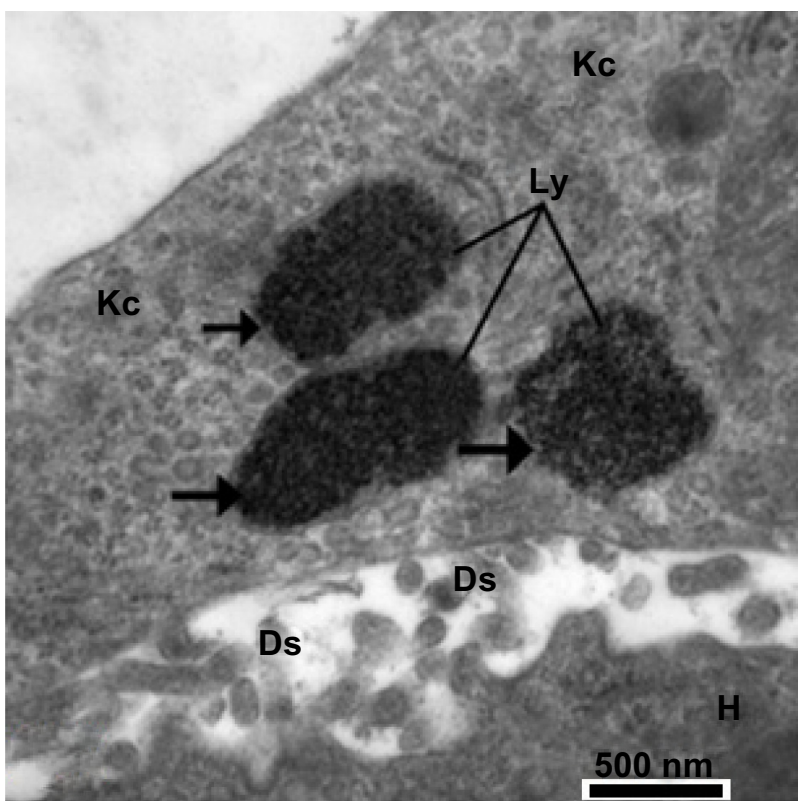

Figure $\mathbf{2 0}$ Higher magnification of the previous image, showing lysosomes in Kupffer cells filled with minute electron-dense silver nanoparticles (arrows). Notice the presence of part of a hepatocyte with its microvilli in Disse's space. Scale bar $500 \mathrm{~nm}$. Abbreviations: Ds, Disse's space; H, hepatocyte; Kc, Kupffer cells; Ly, lysosomes.

Also, the smallest (mean size $2.4 \mathrm{~nm}$ ) gold nanoparticles were found to be localized in the nucleus, ${ }^{39}$ and intermediate ones (size $5.5-8.2 \mathrm{~nm}$ ) were partly delivered into the cytoplasm, causing greater oxidative stress and cytotoxic effects than

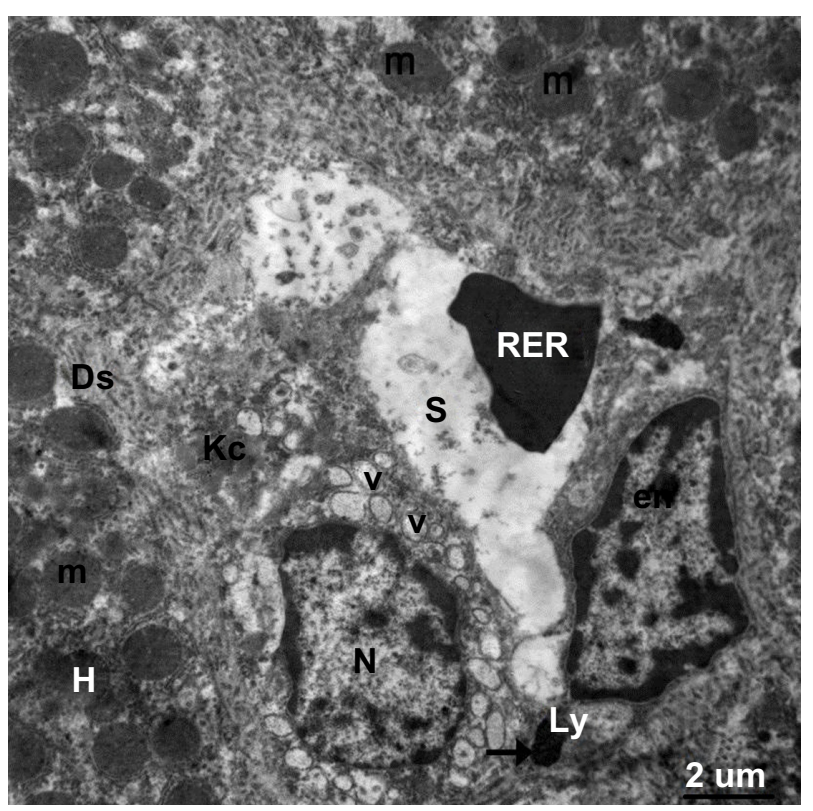

Figure 2I Transmission electron micrograph showing a hepatic cell from the treated group with numerous mitochondria, hypertrophied endothelial and Kupffer cells containing numerous membranous vesicles, and electron-dense silver nanoparticles (arrow) within a lysosome. The blood sinusoid contains an individual red blood cell. Note the fragmented microvilli in Disse's space. Scale bar $2 \mu \mathrm{m}$.

Abbreviations: Ds, Disse's space; en, endothelial cell; $\mathrm{H}$, hepatic cell; Kc, Kupffer cells; Ly, lysosome; m, mitochondria; N, nucleus; RBC, red blood cell; S, blood sinusoid; $\mathrm{V}$, vesicles.
Table I Hematology results from control animals and those treated with silver nanoparticles

\begin{tabular}{lcc}
\hline Hematological parameter & $\begin{array}{l}\text { Control } \\
\text { group }\end{array}$ & $\begin{array}{l}\text { Treated } \\
\text { group }\end{array}$ \\
\hline White blood cells $\left(\times 10^{3} / \mathrm{ul}\right)$ & $9.3 \pm 1.33$ & $1 \mathrm{I} .93 \pm \mathrm{I} . \mathrm{I}^{*}$ \\
Lymphocytes $\left(\times 10^{3} / \mathrm{ul}\right)$ & $8.8 \pm 0.16$ & $9.61 \pm 0.54$ \\
Granulocytes $\left(\times 10^{3} / \mathrm{ul}\right)$ & $0.2 \pm 0.94$ & $0.63 \pm 0.19$ \\
Red blood cells $\left(\times 10^{6} / \mathrm{ul}\right)$ & $6.98 \pm 0.33$ & $6.46 \pm 0.29$ \\
Hemoglobin $(\mathrm{g} / \mathrm{L})$ & $178 \pm 0.46$ & $184 \pm 5.29 *$ \\
Hematocrit $($ Liters/Liter) & $0.387 \pm 1.42$ & $0.35 \pm 019$ \\
Mean corpuscular volume (femtoliter) & $55.5 \pm 2.44$ & $53.47 \pm 1.8 \mathrm{I}$ \\
Mean corpuscular hemoglobin & $25.5 \pm 0.78$ & $26.88 \pm 1.04$ \\
(Picograms) & & \\
MCHC (grams/liter) & $460 \pm 0.22$ & $487.79 \pm 10.44$ \\
\hline
\end{tabular}

Notes: All data are expressed as the mean \pm standard deviation. $P$-values $<0.05$ were considered to be statistically significant. $* P<0.05$ as compared to the control group. Abbreviation: $\mathrm{MCHC}$, mean corpuscular hemoglobin concentration.

larger nanoparticles, ${ }^{40}$ while larger gold nanoparticles $(>16$ $\mathrm{nm}$ ) did not enter cells. ${ }^{39}$ In contrast, no histopathological evidence of tissue damage in response to treatment with gold or titanium dioxide nanoparticles has been observed in murine models, ${ }^{36,41}$ although the presence of these NPs inside intracellular vacuoles as endosomal containment.

The increased levels of silver in the kidney seen in our study are consistent with published literature showing that subchronic oral dosing with AgNPs induces minimal tubular basophilia in addition to unilateral or bilateral mineralization in the rat kidney. ${ }^{16}$ Other investigators have reported deposi-

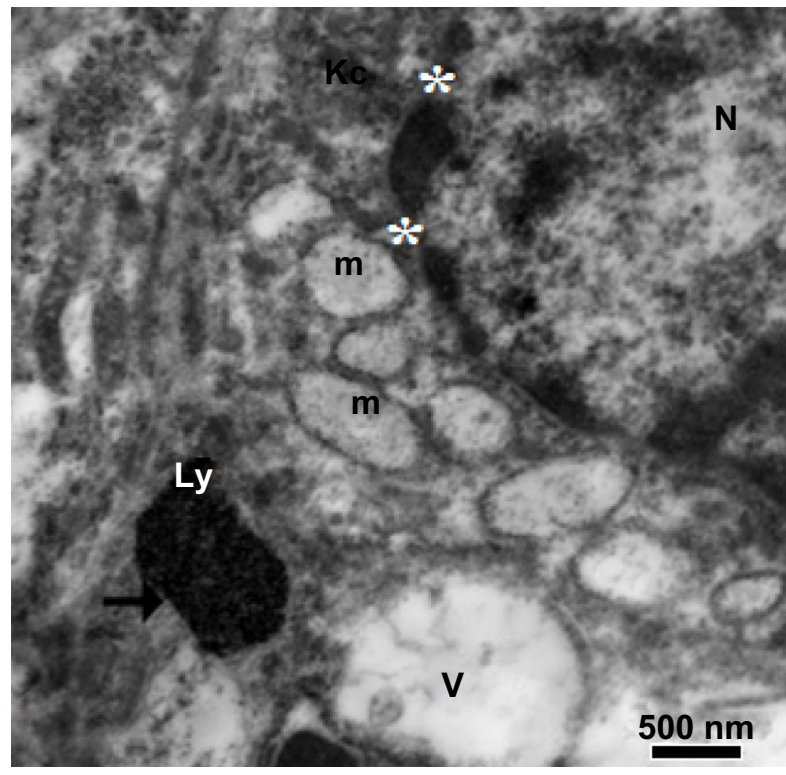

Figure 22 Higher magnification of the previous image, showing a large membranous vacuole, lysosomes in a Kupffer cell filled with minute electron-dense silver nanoparticles (arrow) and mitochondria with destroyed cristae. Note the degenerated nucleus surrounded by a fragmented nuclear envelope (stars). Scale bar $500 \mathrm{~nm}$.

Abbreviations: Kc, Kupffer cell; Ly, lysosome; m, mitochondria; N, nucleus; V, vacuole. 


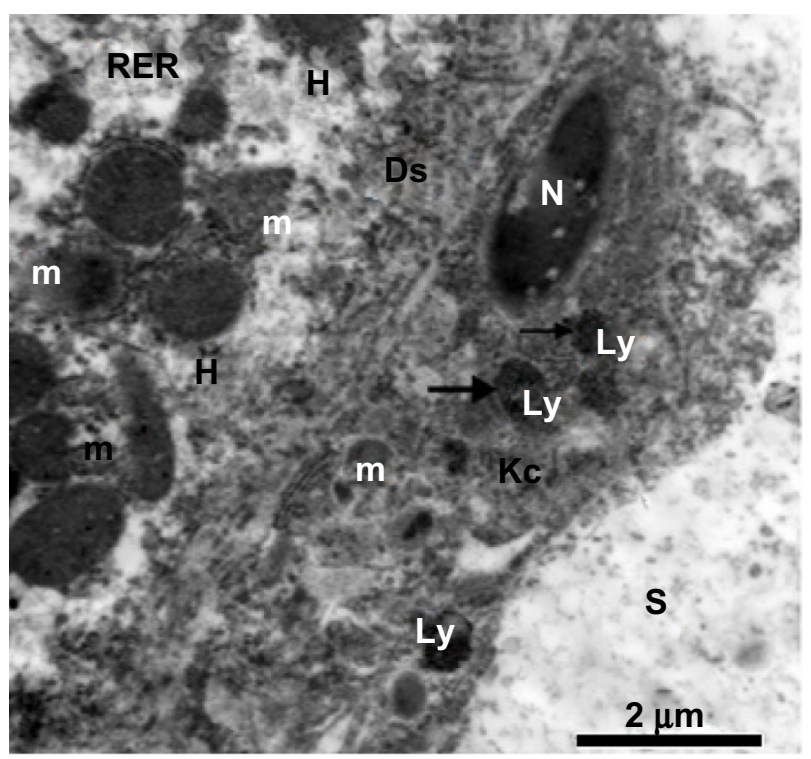

Figure 23 Transmission electron micrograph from the treated group. On the left, there is a cytoplasmic region of a degenerated hepatocyte consisting of numerous degenerated mitochondria, fragmented cisternae in the rough endoplasmic reticulum, and degenerated microvilli in Disse's space. In the middle, there is a degenerated Kupffer cell containing a degenerated nucleus, degenerated mitochondria, and lysosomes filled with silver nanoparticles appearing as electron-dense material (arrows). Scale bar $2 \mu \mathrm{m}$.

Abbreviations: Ds, Disse's space; H, hepatocyte; Kc, Kupffer cell; Ly, lysosomes; $\mathrm{m}$, mitochondria; $\mathrm{N}$, nucleus; RER, rough endoplasmic reticulum; $\mathrm{S}$, blood sinusoid.

A

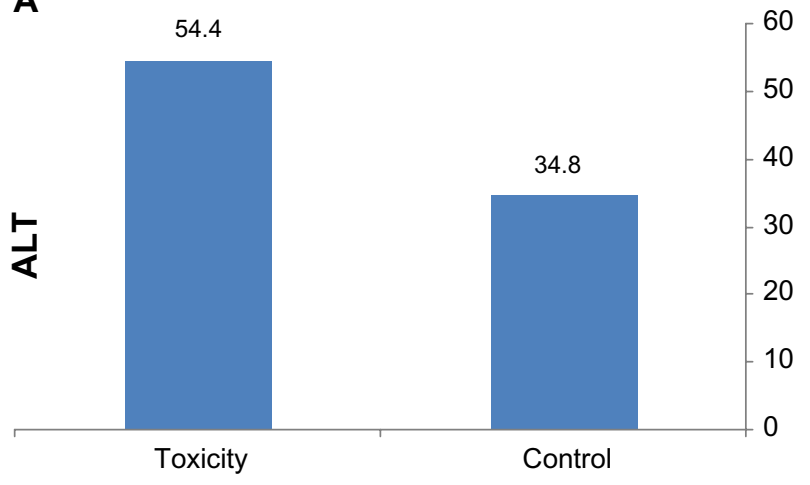

C

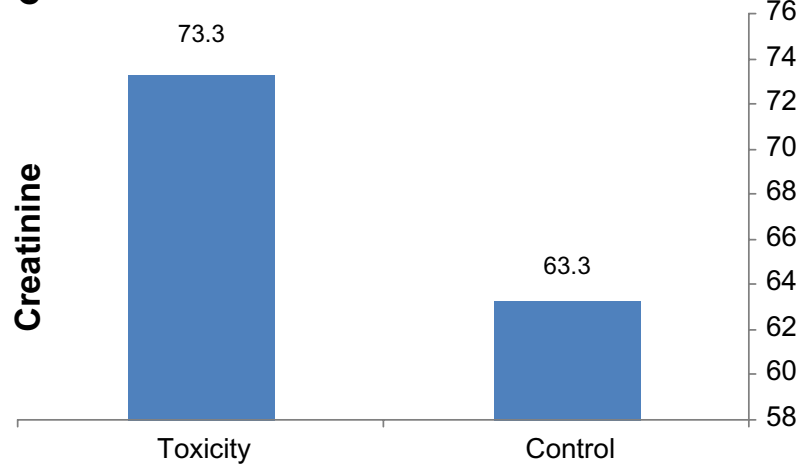

tion of ingested silver in the renal tubules, the glomerular basement membrane, ${ }^{16,42-44}$ and mesangium, ${ }^{45}$ as well as proliferation of mesangial cells. ${ }^{46}$ Further, swelling of the renal epithelium and the presence of membranous vacuoles along with hypertrophied nucleoli have been demonstrated in all animals treated with $\mathrm{AgNPs} .{ }^{44,47-50}$ Moreover, the present work suggests increasing glomerular cellularity and swelling of the primary and secondary processes of podocytes which, to the authors' knowledge, has not been reported before.

With regard to liver toxicity, we found swelling of hepatocytes with prominent hypertrophied nucleoli and narrowing of the sinusoidal lumen. These results are consistent with previous reports of the liver being the target organ for AgNPs and the site at which they preferentially accumulate. ${ }^{11,16,44,51}$ The liver damage seen in the current study may be explained by: deposition of AgNPs in the hepatic Kupffer cells and endothelial cells lining the sinusoidal spaces; $; 2$ inhibition of the mitochondrial respiratory chain that normally produces energy for cells; ; $428,53,54$ generation of reactive oxygen species associated with inflammatory, oxidative, genotoxic, and cytotoxic events; and induction of apoptosis. ${ }^{29,51,53}$

B
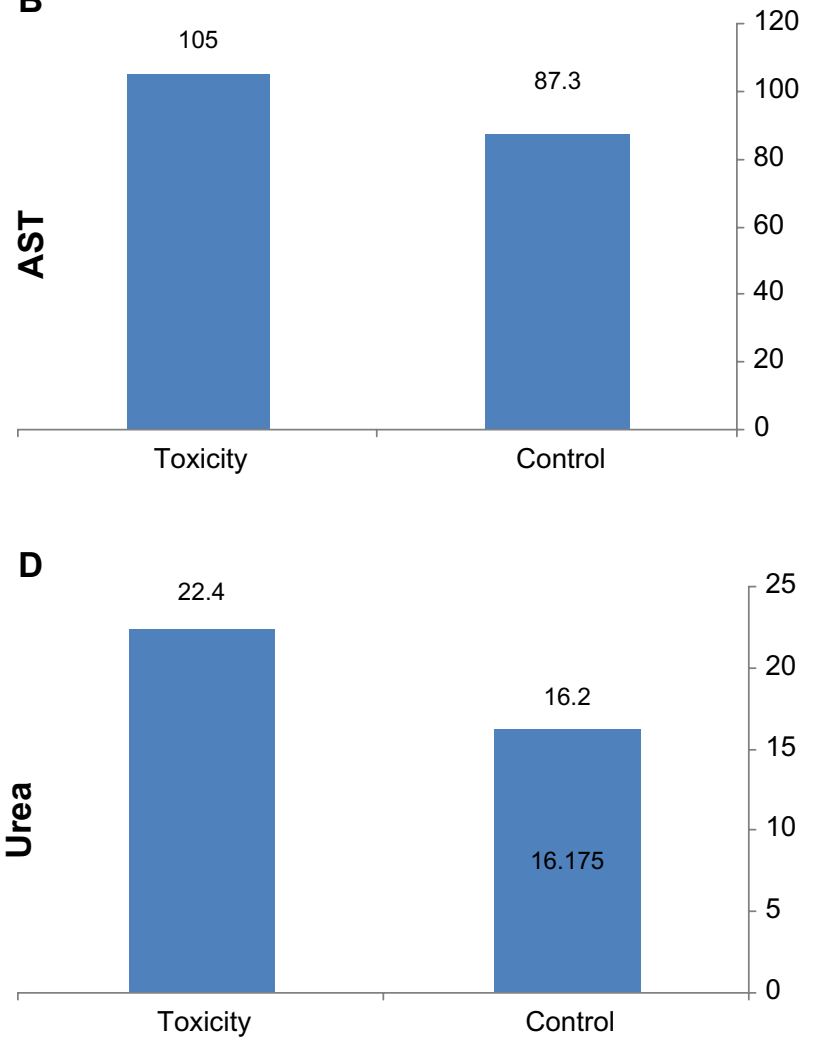

Figure 24 Biochemical results for control and treated rats. (A and B) Concentrations (U/L) of ALT and AST, respectively. (C and D) Concentrations (mg/dL) of creatinine and urea, respectively.

Abbreviations: ALT, alanine transferase; AST, aspartate transferase. 
Endocytosis of AgNPs by numerous endosomes and lysosomes in Kupffer cells was seen in the present work.

Similarly, our observation of intracellular fat globules in the cytoplasm of hepatocytes is new, although empty vacuolelike spaces have been reported in rats. ${ }^{44}$ Also, the first-pass effect of AgNPs in the liver resulted in excretion into the bile, inducing bile duct hyperplasia and focal, multifocal, or lobular necrosis. ${ }^{16}$ Silver had also been shown to be toxic to other organs, including the brain, ${ }^{55}$ and administration of gold nanoparticles has been associated with dilated interlobular sinusoidal capillaries and congestion of blood between hepatocytes in the liver. ${ }^{46}$ AgNPs endocytosed by Kupffer cells that appeared in the form of electron-dense materials were reported. ${ }^{43,50}$

With regard to the mitochondrial injury, this study confirms that the smallest Ag-NPs destructed biomembranes, decreased bioenergetics and adenosine triphosphate (ATP) levels which preceded cell death. Similarly, decreased ATP and creatine kinase levels suggest a potential for metabolic and cell cycle arrest, leading to widespread cell death. ${ }^{50,56}$

Complete blood counts revealed a significant increase in white cells and hemoglobin in the treated group, along with slight changes in red cell and hematocrit values. Moreover, when AgNPs are injected intravenously, they interact initially with the blood and its components and they may cause various immunogenic responses, inflammation, and changes in hematological parameters, including white cells and platelets. ${ }^{26}$ The changes in white and red blood cells reported here after the first injection of nanoparticles have been described before, and are possibly due to an increased immunogenic response $\mathrm{e}^{26,57,58}$ or disturbances in signaling pathways and maturation of cells, ${ }^{59}$ which can affect red blood cells as well as the division and development of other cells.

With regard to biochemistry, significant elevations of serum alanine and aspartate aminotransferase, creatinine, and urea levels were seen, indicating disruptive changes in liver and kidney function. Previous studies have shown that metal nanoparticles alter the levels of various biochemical markers indicating changes in composition of serum enzyme levels, ${ }^{60}$ suggesting hepatocellular injury, hepatic inflammation, and impairment of kidney function..$^{60,61}$

\section{Conclusion}

The aim of this study was to evaluate the potential toxicity of acute dosing with AgNPs. We found that acute doses of AgNPs were not associated with mortality and didn't affect the normal activity (behavior) of examined rats. Renal damage was observed, including swollen epithelium in the renal tubules, cytoplasmic vacuolization, hypertrophied nucleoli, thickening of the basement membrane in the glomerular tufts, and reduction of Bowman's space. On the other hand, liver tissue showed damaged hepatocytes and Kupffer cells with numerous intracellular and intranuclear fat globules, fragmented cisternae in the rough endoplasmic reticulum, and swollen or destroyed mitochondria with complete loss of internal ridges and matrices. It can be concluded that an acute dose of AgNPs will induce significant damage to the structure and function of the liver and kidney, as well as disrupting blood parameters. In this study, the acute dose generated remarkable toxic effect in killing any tumor cells. To protect healthy tissues and to reduce AgNPs toxicity, biodegradable, biocompatible organic substance, polymer matrix or even lipids should be used to encapsulate AgNPs. Further in vivo studies are essential to evaluate the critical concentration needed for AgNPs and to evaluate further ultrastructural effects on the high-energy consuming organs such as brain, skeletal muscles, and heart.

\section{Acknowledgment}

We are most grateful to Professor Ali Gab-Allah of the Faculty of Science at the University of Suez Canal in Egypt for his invaluable insights and suggestions. We also owe a tremendous amount of gratitude to Dr Abduraman A Noor, the CEO of Dr Sulub Leadership Center for his invaluable guidance.

\section{Disclosure}

The authors report no conflicts of interest in this work.

\section{References}

1. Barnes C, Elsaesser A, Arkusz J, et al. Reproducible comet assay of amorphous silica nanoparticles detects no genotoxicity. Nano Lett. 2008;8:3069-3074.

2. Thomas K, Sayre P. Research strategies for safety evaluation of nanomaterials, Part I: evaluating the human health implications of exposure to nanoscale materials. Toxicol Sci. 2005;87:316-321.

3. Drakel PL, Hazelwood KJ. Exposure-related health effects of silver and silver compounds: a review. Ann Occup Hyg. 2005;49:575-585.

4. Chen X, Schluesener HJ. Nanosilver: a nanoproduct in medical application. Toxicol Lett. 2008;176:1-12.

5. Reddy TK, Reddy SJ, Prasad, et al. Effect of silver nanoparticles on energy metabolism in selected tissues of Aeromonas hydrophila infected Indian major Carp, Catlacatla. IOSR J Pharmacy. 2013;3:49-55.

6. Tavares P, Balbinot F, de Olivera HM, et al. Evaluation of genotoxic effect of silver nanoparticles (AgNPs) in vitro and in vivo. $J$ Nanopart Res. 2012;14:791.

7. Maneewattanapinyo P, Banlunara W, Thammacharoen C, Ekgasit S, Kaewamatawong K. An evaluation of acute toxicity of colloidal silver nanoparticles. J Vet Med Sci. 2011;73:1417-1423.

8. Khodadadi S, Naghsh N, Mashayekh A. Effect of silver nanoparticle on phosphocreatine kinase and histological changes of skeletal muscle tissue in male Wistar rat. Available from: http://congress.mazums. ac.ir/jmums/files/site1/user_files_0d0bf0/t_mousavi-A-10-1466-21e3892c2.pdf. Accessed February 5, 2014. 
9. Tiwari DK, Jin T, Behari J. Dose-dependent in-vivo toxicity assessment of silver nanoparticle in Wistar rats. Toxicol Mech Methods. 2011;21: 13-24.

10. Atiyeh BS, Costagliola M, Hayek SN, Dipo SA. Effect of silver on burn wound infection control and healing: review of the literature. Burns. 2007;33:139-148.

11. Sardari RR, Zarchi SR, Talebi A, et al. Toxicological effects of silver nanoparticles in rats. Afr J Microbiol Res. 2012;6:5587-5593.

12. Park E, Bae E. Repeated-dose toxicity and inflammatory responses in mice by oral administration of silver nanoparticles. Environ Toxicol Pharm. 2010;30:162-168.

13. Kim JS, Song KS, Sung TH, et al. Genotoxicity, acute oral and dermal eye and dermal irritation and corrosion and skin sensitization evaluation of silver nanoparticles. Nantoxicology. 2013;7:953-960.

14. Braydich-Stolle L, Hussain S, Schlager JJ, Hofmann MC. In vitro cytotoxicity of nanoparticles in mammalian germline stem cells. Toxicol Sci. 2005;88:412-419.

15. Tang J. Status of biological evaluation on silver nanoparticles. J Biomed Eng. 2008;25:958-961.

16. Kim YS, Song MY, Park JD, et al. Subchronic oral toxicity of silver nanoparticles. Part Fibre Toxicol. 2010;10:20.

17. Reitman S, Frankel S. A colourimetric method of serum glutamic oxalo acetic and glutamic pyruvic transaminases. Am J Clin Pathol. 1975;28: 56-63.

18. Henry RJ. Clinical Chemistry. Principles and Techniques. 2nd ed. Hagerstown, MD, USA: Harper and Row; 1974.

19. Bozzola JJ, Russell LD. Specimen staining and contrast methods for transmission electron microscopy. In: Bozzola JJ, Russell LD, editors. Electron Microscopy. Principles and Techniques for Biologists. Boston, MA, USA: Jones and Bartlett Publishers, Boston; 1992;5.

20. Choi O, Deng KK, Kim NJ, Ross L Jr, Surampalli RY, Hu Z. The inhibitory effects of silver nanoparticles, silver ions, and silver chloride colloids on microbial growth. Water Res. 2008;42:3066-3074.

21. Ruparelia JP, Chatterjee AK, Duttagupta SP, Mukherji S. Strain specificity in antimicrobial activity of silver and copper nanoparticles. Acta Biomater. 2008;4:707-716.

22. Moghimi SM, Hunter AC, Murray JC. Long-circulating and targetspecific nanoparticles: theory to practice. Pharmacol Rev. 2001;53: 283-318.

23. Panyam J, Labhasetwar V. Biodegradable nanoparticles for drug and gene delivery to cells and tissue. Adv Drug Deliv Rev. 2003;55: 329-347.

24. Alt V, Bechert T, Steinrücke $P$, et al. An in vitro assessment of the antibacterial properties and cytotoxicity of nanoparticulate silver bone cement. Biomaterials. 2004;25:4383-4391.

25. Kawata K, Osawa M, Okabe S. In vitro toxicity of silver nanoparticles at noncytotoxic doses to HepG2 human hepatoma cells. Environ Sci Technol. 2009;43:6046-6051.

26. Kim S, Choi JE, Choi J, et al. Oxidative stress-dependent toxicity of silver nanoparticles in human hepatoma cells. Toxicol in Vitro. 2009;23: 1076-1084

27. Huo Y, Li G, Duan RF, et al. PTEN deletion leads to deregulation of antioxidants and increased oxidative damage in mouse embryonic fibroblasts. Free Radic Biol Med. 2008;44:1578-1591.

28. Costa CS, Ronconi JVV, Daufenbach JE, et al. In vitro effects of silver nanoparticles on the mitochondrial respiratory chain. Mol Cell Biochem. 2010;342:51-56.

29. Kim S, Kim S, Lee S, et al. Characterization of the effects of silver nanoparticles on liver cells using HR-MAS NMR spectroscopy. Bull Korean Chem Soc. 2011;32:2021-2026.

30. Abdelhalim MA. Gold nanoparticles administration induces disarray of heart muscle; hemorrhagic, chronic inflammatory cells infiltrated by small lymphocytes, cytoplasmic vacuolization and congested blood vessels. Lipids Health Dis. 2011;10:233-241.

31. Yasin S, Liu L, Yao J. Biosynthesis of silver nanoparticles by bamboo leaves extract and their antimicrobial activity. Journal of Fiber Bioengineering and Informatics. 2013;6(1):77-84.
32. Jiang W, Kim BY, Rutka JT, Chan WC. Nanoparticle-mediated cellular response is size-dependent. Nat Nanotechnol. 2008;3:145-150.

33. Wei L, QunFang Z, JiYan L, et al. Environmental and biological influences on the stability of silver nanoparticles. Chinese Science Bulletin. 2011;56:2009-2015.

34. Gilbert B, Ono RK, Ching KA, et al. The effects of nanoparticle aggregation processes on aggregate structure and metal uptake. J Colloid InterfSci. 2009;339:285-295.

35. Wick P, Manser P, Limbach LK, et al. The degree and kind of agglomeration affect carbon nanotube cytotoxicity. ToxicolLett. 2007;168: 121-131.

36. Umbreit TH, Franke-Carroll S, Weaver JL, et al. Tissue distribution and histopathological effects of titanium dioxide nanoparticles after intravenous or subcutaneous injection in mice. J Appl Toxicol. 2012;32: 350-357.

37. Austin CA, Umbreit TH, Brown KM, et al. Distribution of silver nanoparticles in pregnant mice and developing embryos. Nanotoxicology. 2012;6:912-922.

38. Hillyer JF, Albrecht RM. Gastrointestinal persorption and tissue distribution of differently sized colloidal gold nanoparticles. J Pharm Sci. 2001;90:1927-1936.

39. Oh E, Delehanty JB, Sapsford KE, et al. Cellular uptake and fate of PEGylated gold nanoparticles is dependent on both cell-penetration peptides and particle size. ACS Nano. 2011;5:6434-6448.

40. Pan Y, Leifert A, Ruau D, et al. Gold nanoparticles of diameter $1.4 \mathrm{~nm}$ trigger necrosis by oxidative stress and mitochondrial damage. Small. 2009;5:2067-2076.

41. Zhang Q, Hitchins VM, Scharand AM, Hussain SM, Goering PL. Uptake of gold nanoparticles in murine macrophage cells without cytotoxicity or production of pro-inflammatory mediators. Nanotoxicology. 2011;5:284-295.

42. Moffat DB, Creasey M. The distribution of ingested silver in the kidney of the rat and of the rabbit. Acta Anat. 1972;83:346-355.

43. Loeschner K, Hadrup N, Qvortrup K, et al. Distribution of silver in rats following 28 days of repeated oral exposure to silver nanoparticles or silver acetate. Part Fibre Toxicol. 2011;8:18.

44. Yousef J, Hendi H, Hakami SF, et al. Toxicity of silver nanoparticles after Injected intraperitoneally in rats. J Am Sci. 2012;8:589-593.

45. Day WA, Hunt JS, McGiven AP. Silver deposition in mouse glomeruli. Pathology. 1976;8:201-204.

46. Terentyuk GN, Maslyakova GN, Suleymanova LV, et al. Morphological and biochemical changes after intravenous injection of gold nanoparticles. SPIE Proceedings of 7th international Conference on Photonics and Imaging in Biology and Medicine. 2009;7280:155-163.

47. Derfus AM, Chan WCW, Bhatia SN. Intracellular delivery of quantum dots for live cell labeling and organelle tracking. Adv Mater. 2004;16: 961-966.

48. Kogan MJ, Bastus NG, Amigo R, et al. Nanoparticle-mediated local and remote manipulation of protein aggregation. Nano Lett. 2006;6: $110-115$.

49. Noginov MA, Zhu G, Bahoura M, et al. The effect of gain and absorption on surface plasmos in metal nanoparticles. Appl Phys B. 2007;86: 455-460.

50. Asharani PV, Mun GLK, Hande MP, Valiyaveettil S. Cytotoxicity and genotoxicity of silver nanoparticles in human cells. ACS Nano. 2009;3:279-290.

51. Johnston HJ, Hutchison G, Christensen FM, Peters S, Hankin S, Stone $\mathrm{V}$. A review of the in vivo and in vitro toxicity of silver and gold particulates: particle attributes and biological mechanisms responsible for the observed toxicity. Crit Rev Toxicol. 2010;40:328-346.

52. Danscher G. Light and electron microscopic localization of silver in biological tissue. Histochemistry. 1981;71:171-186.

53. Hussain SM, Hess KL, Gearhart JM, Geiss KT, Schlager JJ. In vitro toxicity of nanoparticles in BRL 3A rat liver cells. Toxicol In Vitro. 2005;19:975-983.

54. Asharani PV, Hande MP, Valiyaveettil S. Anti-proliferative activity of silver nanoparticles. BMC Cell Biol. 2009;10:65. 
55. Ahamed M, Alsalhi MS, Siddiqui MK. Silver nanoparticle applications and human health. Clin Chim Acta. 2010;411:1841-1848.

56. Paula MM, da Costa CS, Baldin NC, et al. In vitro effect of silver nanoparticles on creatine kinase activity. J Braz Chem Soc. 2009;20: $1556-1560$.

57. Duffin R, Tran L, Brown D, Stone V, Donaldson K. Proinflammogenic effects of low-toxicity and metal nanoparticles in vivo and in vitro: highlighting the role of particle surface area and surface reactivity. Inhal Toxicol. 2007;19:849-856.

58. Shin SH, Ye MK, Kim HS, Kang HS. The effects of nanosilver on the proliferation and cytokine expression by peripheral blood mononuclear cells. Int Immunopharmacol. 2007;7:1813-1818.
59. Gopinath P, Gogoi SK, Sanpui P et al. Signaling gene cascade in silver nanoparticle induced apoptosis. Colloid Surf B Biointerfaces. 2010;77: 240-245.

60. Kim YS, Kim JS, Cho HS, et al. Twenty-eight-day oral toxicity, genotoxicity, and gender-related tissue distribution of silver nanoparticles in Sprague-Dawley rats. Inhal Toxicol. 2008;20:575-583.

61. Loeb WF, Quimby FW, editors. The Clinical Chemistry of Laboratory Animals. 2nd ed. Philadelphia, PA, USA: Taylor \& Francis; 1999.
International Journal of Nanomedicine

\section{Publish your work in this journal}

The International Journal of Nanomedicine is an international, peerreviewed journal focusing on the application of nanotechnology in diagnostics, therapeutics, and drug delivery systems throughout the biomedical field. This journal is indexed on PubMed Central, MedLine, CAS, SciSearch ${ }^{\circledR}$, Current Contents ${ }^{\circledR} /$ Clinical Medicine,

\section{Dovepress}

Journal Citation Reports/Science Edition, EMBase, Scopus and the Elsevier Bibliographic databases. The manuscript management system is completely online and includes a very quick and fair peer-review system, which is all easy to use. Visit http://www.dovepress.com/ testimonials.php to read real quotes from published authors.

Submit your manuscript here: http://www.dovepress.com/international-journal-of-nanomedicine-journal 